\title{
Pengaruh Teknik Distraksi Guidance Imagery Terhadap Tingkatan Ansietas Pada Pasien Pra Bedah Di Rsud Linggajati Kabupaten Kuningan
}

\author{
${ }^{1}$ Norma Mardiani, ${ }^{2}$ Budi Hermawan \\ Stikes Mahardhika Cirebon \\ Email: ${ }^{1}$ normamardiani@gmail.com, ${ }^{2}$ hemawanbudi@gmail.com
}

\begin{abstract}
The surgery will evoke stress reactions both physiologically and psychologically. One of the psychological responses is anxiety. One relaxation technique used to treat anxiety in patients is guided imagery therapy, since relaxation techniques are an action to divert attention and reduce the anxiety that patients experience. This study aims to determine the effect of guided imagery therapy on changes in anxiety levels in patients before surgery. Design this research with one group pretest posttest design approach. Population in this research is pre surgical patient at Linggajati General Hospital Kuningan. The sampling technique used is purposive sampling, so the sample of this study is 30 patients of pre-surgery at Linggajati Kuningan Hospital. Analyzer used with paired sample $t$ test. Results: The results of the study revealed that: 1) The level of patient anxiety before the technique of distraction of guidance imagery at Linggajati Kuningan Hospital is in the medium category; 2) The level of anxiety of patients after the technique of distraction of guidance imagery at Linggajati Kuningan Hospital included in the mild category has increased; 3) There are effect distraction guided imagery technique to the level of anxiety in the preoperative patient at Linggajati Kuningan Hospital. The result oh the experiment shows that guided imagery can reduce a level of anxiety in pre operative patient at Linggajati General Hospital Kuningan.
\end{abstract}

Keywords : Guided Imagery, Anxiety

\begin{abstract}
Abstrak.Pembedahan akan membangkitkan reaksi stress baik fisiologis maupun psikologis. Salah satu respon psikologis adalah kecemasan.Salah satu teknik relaksasi yang digunakan untuk mengatasi kecemasan pada pasien adalah dengan terapi guided imagery, karena teknik relaksasi merupakan tindakan untuk mengalihkan perhatian dan mengurangi rasa cemas yang di alami pasien. Penelitian ini bertujuan untuk mengetahui pengaruh pemberian terapi guided imagery terhadap perubahan tingkat kecemasan pada pasien pra bedah. Desain penelitian ini dengan pendekatan one group pretest posttest design. Populasi dalam penelitian ini adalah pasien pra bedah di RSUD Linggajati Kuningan. Teknik pengambilan sampel yang digunakan adalah purposive sampling, sehingga sampel penelitian ini adalah 34 pasien pra bedah di RSUD Linggajati Kuningan. Alat analisis yang digunakan dengan paired sample t test. Hasil penelitian diketahui bahwa: 1) Tingkat kecemasan pasien sebelum dilakukan teknik distraksi guidance imagery di RSUD Linggajati Kuningan termasuk dalam kategori sedang; 2) Tingkat kecemasan pasien sesudah dilakukan teknik distraksi guidance imagery di RSUD Linggajati Kuningan termasuk dalam kategori ringan mengalami peningkatan; 3) Ada pengaruh pemberian teknik distraksi guided imagery terhadap tingkat kecemasan pada pasien pra bedah di RSUD Linggajati Kuningan. Hasil penelitian menunjukkan guidance imagery dapat menurunkan tingkat kecemasan pada pasien pra bedah di RSUD Linggajati Kuningan.
\end{abstract}

Kata Kunci : Teknik Distraksi Guidance Imagery, Ansietas 


\section{A. PENDAHULUAN}

Tindakan pembedahan merupakan salah satu tindakan medis yang akan mendatangkan stressor terhadap integritas seseorang (Ferlina dalam Mashudi, 2011). Hampir sebagian besar pasien yang akan menjalani operasi mengalami ansietas karena menganggap tindakan operasi merupakan pengalaman yang menakutkan. Ansietas merupakan pengalaman subjektif dari individu dan tidak dapat di observasi secara langsung serta merupakan keadaan emosi tanpa subjek yang spesifik. (Suliswati,2005).

\begin{tabular}{ccc}
\multicolumn{2}{r}{ Seseorang yang } & mengalami \\
ansietas & akan & mengalami
\end{tabular} ketidakseimbangan secara fisik dan mencetuskan beberapa sensasi dan perubahan fisik, meliputi peningkatan aliran darah menuju otot, ketegangan otot, mempercepat dan memperlambat pernafasan, meningkatkan denyut jantung dan menurunkan fungsi digestif (stuart \& Laraia, 2005).

\section{Data World Health}

Organization (WHO) (2007), Amerika Serikat menganalisis data dari 35.539 klien bedah dirawat di unit perawatan intensif antara 1 Oktober 2003 dan 30 September 2006. Dari 8.922 pasien $(25,1 \%)$ mengalami kondisi kejiwaan dan 2.473 klien (7\%) mengalami kecemasan (Chandra, 2014). Penelitian yang dilakukan oleh Ferlina Indra S (2012) tentang tingkat ansietas prabedah di Rumah Sakit Umum Daerah (RSUD) Sragen, bahwa dari 40 orang responden yang menjalani operasi dalam tingkat kecemasan berat sebanyak 7 orang (17,5\%), 16 orang $(40 \%)$ yang memiliki tingkat kecemasan sedang, 15 orang $(37,5 \%)$ ringan dan 2 orang (2\%) responden yang tidak merasa cemas (Chandra, 2014).

Berdasarkan data rekapitulasi kegiatan pembedahan dengan berbagai diagnosa di RSUD Linggajati Kabupaten Kuningan, pada bulan Januari - Desember 2016, yaitu sebanyak 387 orang. Pasien yang menjalani operasi bedah umum sebanyak 192 orang dan yang menjalani operasi orthopedi sebanyak 195 orang. Data yang diperoleh pembatalan pasien yang akan menjalani operasi pada bulan Januari - Maret 2017 kasus pembatalan atau penundaan operasi sebanyak 3 kasus di sebabkan karena peningkatan tekanan darah dan 1 kasus penolakan karena keluarga menolak dan pasienya mengalami ansietas berat. Tindakan keperawatan yang dilakukan pasien prabedah, yaitu pendidikan kesehatan, nafas dalam, informed concent dan terapi diet (Data bedah RSUD Linggajati, 2006).

Perawat sebagai tenaga paramedis di rumah sakit memiliki peran yang sangat penting dalam membantu pasien mengatasi kecemasan (Sheldon Kennedy, 2009). Salah satu penatalaksanaan non farmakologi yang bisa dilakukan untuk mengurangi ansietas itu sendiri adalah dengan cara relaksasi. Relaksasi merupakan suatu bentuk teknik yang melibatkan pergerakan anggota badan dan bisa 
dilakukan dimana saja (Potter \& Perry, 2005). Pada saat tubuh dan pikiran relaks, secara otomatis ketegangan yang seringkali membuat otot-otot mengencang akan diabaikan (Zalaquett \& McCraw, 2000). Berdasarkan hal tersebut, sangat penting untuk mengetahui pengaruh teknik Distraksi Guidance Imagery Terhadap Tingkatan Ansietas Pada Pasien Pra Bedah di ruang Bedah RSUD Linggajati.

\section{B. METODE PENELITIAN}

Penelitian ini menggunakan rancangan penelitian quasy eksperiment dengan pretest-postest with control group Design. Populasi pasien dalam penelitian ini adalah pasien yang akan menjalani pembedahan di ruang bedah RSUD Linggajati Kuningan dengan teknik total sampling berjumlah 30 pasien fraktur.

\section{HASIL PENELITIAN DAN PEMBAHASAN}

1. Tingkat kecemasan pasien sebelum dilakukan teknik guided imagery di Ruang bedah Di RSUD Linggajati Kabupaten Kuningan adalah sebagai berikut :

Tabel 1. Distribusi Frekuensi berdasarkan Tingkat kecemasan sebelum dilakukan Teknik Distraksi Guidance Imagery $(\mathrm{n}=30)$

\begin{tabular}{|l|l|l|}
\hline Kecemasan & Frekuensi & Presentase (\%) \\
\hline Tidak Cemas & 0 & 0 \\
Cemas Ringan & 8 & 26,7 \\
Cemas & 22 & 73,3 \\
Sedang & 0 & 0 \\
Cemas Berat & & \\
\hline Total & 30 & 100 \\
\hline
\end{tabular}

Berdasarkan tabel 1, diketahui bahwa $73,3 \%$ atau 22 responden termasuk dalam kategori tingkat kecemasan sedang dan $6,7 \%$ atau 8 responden mempunyai tingkat kecemasan yang termasuk dalam kategori ringan, sehingga dapat diketahui bahwa mayoritas responden sebelum dilakukan teknik distraksi guided imagery di RSUD Linggajati Kabupaten Kuningan mempunyai tingkat kecemasan yang termasuk dalam kategori sedang.

2. Tingkat kecemasan pasien sesudah dilakukan teknik distraksi guided imagery di ruang bedah di RSUD Linggajati Kabupaten Kuningan adalah sebagai berikut :

Tabel 2. Distribusi Frekuensi berdasarkan Tingkat kecemasan sesudah dilakukan Teknik Distraksi Guidance Imagery $(n=30)$

\begin{tabular}{|l|l|l|}
\hline Kecemasan & Frekuensi & $\begin{array}{l}\text { Presentase } \\
(\boldsymbol{\%})\end{array}$ \\
\hline Tidak Cemas & 10 & 33,3 \\
Cemas Ringan & 18 & 60 \\
Cemas Sedang & 2 & 6,7 \\
\hline Total & 30 & 100 \\
\hline
\end{tabular}

Pada tabel 2 Tingkat kecemasan responden sesudah dilakukan teknik guided imagery diketahui bahwa $60 \%$ atau 18 responden mempunyai tingkat kecemasan yang termasuk dalam kategori ringan dan $33,3 \%$ atau 10 responden termasuk dalam kategori tidak mengalami kecemasan, dan 6,7\% atau 2 responden mempunyai tingkat kecemasan sedang, sehingga dapat diketahui bahwa mayoritas pasien sesudah dilakukan teknik guided imagery di RSUD Linggajati Kabupaten Kuningan mempunyai 
tingkat kecemasan yang termasuk dalam kategori ringan.

3. Hubungan perawatan luka diabetik konvensional dengan penyembuhan luka diabetik Di RSUD Linggajati Kuningan.

Tabel 3 Pengaruh Teknik Distraksi Guided imagery Terhadap Tingkat Kecemasan

\begin{tabular}{|c|c|c|c|c|}
\hline $\begin{array}{l}\text { Teknik } \\
\text { Terapi } \\
\text { Guided } \\
\text { imagery }\end{array}$ & $\mathbf{N}$ & $\begin{array}{l}\text { Rata- } \\
\text { rata }\end{array}$ & $\begin{array}{l}\text { t } \\
\text { Hitung }\end{array}$ & $p$ \\
\hline $\begin{array}{l}\text { Sebelum } \\
\text { Intervensi } \\
\text { Sesudah } \\
\text { Intervensi }\end{array}$ & $\begin{array}{l}30 \\
30\end{array}$ & $\begin{array}{l}17,88 \\
15,74\end{array}$ & 10,573 & 0,001 \\
\hline Total & 30 & & & \\
\hline
\end{tabular}

Berdasarkan tabel 3 diperoleh nilai rata-rata tingkat kecemasan sebesar 17,88, sedangkan sesudah dilakukan teknik distraksi guided imagery diperoleh nilai rata-rata tingkat kecemasan sebesar 15,74 menunjukkan adanya kecenderungan terjadinya penurunan tingkat kecemasan sesudah dilakukan teknik distraksi guided imagery. Berdasarkan hasil uji Paired Sample $\mathrm{t}$ test diperoleh nilai $\mathrm{t}$ hitung= 10,573 dengan $p=0,001$. Oleh karena hasil perhitungan menunjukkan bahwa $p<0,05$ maka H0 ditolak, artinya ada pengaruh teknik distraksi guided imagery terhadap tingkat kecemasan pada pasienpre operasi di RSUD Linggajati Kuningan.

\section{PEMBAHASAN}

Tingkat Kecemasan Pasien Sebelum Dilakukan Teknik Distraksi Guided imagery

Tingkat kecemasan pasien sebelum dilakukan teknik distraksi guided imagery di RSUD Linggajati Kuningan diketahui bahwa $73,3 \%$ atau 22 responden termasuk dalam kategori tingkat kecemasan sedang dan 6,7\% atau 8 responden mempunyai tingkat kecemasan yang termasuk dalam kategori ringan, sehingga dapat diketahui bahwa mayoritas responden sebelum dilakukan teknik distraksi guided imagery mempunyai tingkat kecemasan yang termasuk dalam kategori sedang.

Pasien pre operasi akan mengalami gangguan alam perasaan (affective) yang ditandai dengan perasaan ketakutan atau kekhawatiran yang mendalam dan berkelanjutan, sehingga menyebabkan gangguan dalam menilai realitas, kepribadian utuh, perilaku dapat terganggu tapi masih dalam batas normal, ini menandakan bahwa mereka mengalami gejala kecemasan (Hawari, 2007). Penyebab cemas diantaranya adanya perasaan takut tidak diterima dalam lingkungan tertentu, adanya pengalaman traumatis, seperti trauma perpisahan, kehilangan atau bencana alam, adanya frustasi akibat kegagalan memenuhi kebutuhan fisiologis (kebutuhan dasar) dan adanya ancaman pada konsep diri (Pieter, dkk, 2011), sehingga perlu adanya tindakan keperawatan dalam mengatasi terjadinya kecemasan pada pasien.

Tindakan keperawatan untuk penanganan masalah kecemasan pasien yaitu dapat berupa tindakan mandiri oleh perawat, contoh seperti teknik relaksasi dan distraksi (Potter \& Perry 2005). Hasil penelitian ini relevan 
dengan penelitian Patasik, dkk (2013) yang menunjukkan kesimpulan dari penelitian ini yaitu tingkat kecemasan pada pasien post operasi caesarea sebelum dilakukan teknik relaksasi nafas dalam dan guided imagerydi Irina D BLU RSUP Prof. Dr. R. D. Kandou Manado sebagian besar mengalami tingkat kecemasan yang tinggi sampai sangat sangat tinggi. Namun hal ini berbeda dengan pendapat Beck (2006) dalam Greenberger \& Padesky, (2009) memberikan pandangan bahwa kecemasan disebabkan oleh pola pikir yang mengarah pada suasana hati depresi atau tertekan. Pikiran-pikiran negatif tentang diri (self criticism), tentang dunia (general negativity), dan tentang masa depan (hopelessness) menjadi faktor penyebab kecemasan.

\section{Tingkat Kecemasan Pasien Sesudah Dilakukan Teknik Distraksi Guided imagery.}

Tingkat kecemasan responden sesudah dilakukan teknik guided imagery di diketahui bahwa $60 \%$ atau 18 responden mempunyai tingkat kecemasan yang termasuk dalam kategori ringan dan $33,3 \%$ atau 10 responden termasuk dalam kategori tidak mengalami kecemasan, dan 6,7\% atau 2 responden mempunyai tingkat kecemasan sedang, mayoritas pasien sesudah dilakukan teknik guided imagery di RSUD Linggajati Kabupaten Kuningan mempunyai tingkat kecemasan yang termasuk dalam kategori ringan.

Salah satu teknik relaksasi yang digunakan untuk mengatasi kecemasan pada pasien adalah dengan terapi guided imagery, karena teknik relaksasi merupakan tindakan untuk mengalihkan perhatian dan mengurangi rasa cemas yang dialami pasien.

Guided imagery merupakan suatu teknik yang menggunakan imajinasi individu dengan imajinasi terarah untuk mengurangi stres (Patricia dalam Kalsum, 2012). Penelitian Kalsum, et al (2012) menunjukkan bahwa teknik guided imagery dapat menurunkan tingkat kecemasan pada klien dengan insomnia usia 20-25. Setelah dilakukan teknik guided imagery diperoleh $81 \%$ subjek penelitian mengalami mengalami penurunan tingkat kecemasan dan $19 \%$ subjek penelitian tingkat kecemasannya tetap.

Berdasarkan hasil uji statistik maka teknik guided imagery dapat digunakan sebagai salah satu metode alternatif untuk menurunkan tingkat kecemasan (Beebe \& Wyatt, 2009). Hasil penelitian ini sesuai dengan Pariman (2013) yang menunjukkan hasil penelitian bahwa tahapan guided imagery melibatkan identifikasi sumber permasalahan dengan pencatatan diri setelah mendengarkan musik dalam keadaan rileks dan mata terpejam tahapan berikutnya, membangun bayangan-bayangan positif dengan guided imagery yang dilakukan setiap harinya. Dengan mengganti pemikiran yang tidak logis, individu akan lebih mampu menilai situasi yang dihadapinya secara lebih objektif.

$$
\text { Keadaan yang demikian, }
$$


memungkinkan individu terbebas dari depresi dan berbagai gangguan emosional lainnya. Namun hasil yang ditemukan pada penelitian yang dilakukan Kaplan dan Saddock (2010), menunjukkan bahwa wanita mempunyai resiko memiliki tingkat kecemasan tinggi dua kali lebih besar dibandingkan dengan pria. Hal ini ditunjukkan banyaknya wanita yang berkonsultasi pada psikolog ataupun bantuan orang lain untuk membantu memecahkan masalah yang sedang dihadapinya, sehingga perlu dilakukan beberapa kali terapi yang dapat menurunkan tingkat kecemasan.

\section{Pengaruh Teknik Distraksi Guided imagery Terhadap Tingkat Kecemasan Pada Pasien Pra Bedah.} Pengaruh teknik distraksi guided imagery terhadap penurunan tingkat kecemasan pada pasien pre operasi diketahui bahwa sebelum dilakukan teknik terapi guided imagery diperoleh nilai rata-rata tingkat kecemasan sebesar 17,88, sedangkan sesudah menjalani teknik terapi guided imagery diperoleh nilai rata-rata tingkat kecemasan sebesar 15,74 menunjukkan adanya kecenderungan terjadinya penurunan tingkat kecemasan sesudah dilakukan teknik terapi guided imagery.

Berdasarkan hasil uji Paired Sample $t$ test diperoleh nilai $\mathrm{t}$ hitung $=$ 10,573 dengan $\mathrm{p}=0,001$. Oleh karena hasil perhitungan menunjukkan bahwa $\mathrm{p}<0,05$ maka H0 ditolak, artinya ada pengaruh pemberian teknik distraksi guided imagery terhadap tingkat kecemasan pada pasien pra bedah di RSUD Linggajati Kuningan.
Guided imagery merupakan suatu teknik yang menggunakan imajinasi individu dengan imajinasi terarah untuk mengurangi stres (Patricia dalam Kalsum, 2012). Snyder \& Lindquist (2002) mendefinisikan bimbingan imajinasi sebagai intervensi pikiran dan tubuh manusia menggunakan kekuatan imajinasi untuk mendapatkan affect fisik, emosional maupun spiritual.

Guided imagery dikategorikan dalam terapi mind-body medicine oleh Bedford (2012) dengan mengombinasikan bimbingan imajinasi dengan meditasi pikiran sebagai crossmodal adaptation. Imajinasi merupakan representasi mental individu dalam tahap relakasasi. Imajinasi dapat dilakukan dengan berbagai indra antata lain visual, auditor, olfaktori maupun taktil. Bimbingan imajinasi merupakan teknik yang kuat untuk dapat fokus dan berimajinasi yang juga merupakan proses terapeutik (Bonadies, 2009). Watanabe et al (2006) membuktikan hasil penelitiannya yang menyebutkan bahwa bimbingan imajinasi meningkatkan mood positif dan menurunkan mood negatif individu secara signifikan dan level kortisol yang diukur menggunakan saliva test juga menunjukkan penurunan yang signifikan.

Namun berdasarkan penelitian Pariman (2013) berbagai tinjauan yang didapatkan dapat ditarik kesimpulan bahwa guided imagery mampu untuk mengurangi tingkat depresi pada penderita kanker. Guided imagery dimungkinkan bisa menjadi salah satu 
alternatif penanganan depresi dan gangguan emosional lainnya.

Pasien yang akan operasi tidak terlepas dari perasaan cemas. Dimana kecemasan tersebut seringkali meningkat menjelang operasi. Guided imagery merupakan salah satu metode yang dapat digunakan untuk mengurangi kecemasan. Untuk membuktikan hal tersebut, maka dilakukanlah eksperimen ini. Penelitian ini berhasil menunjukkan bahwa terdapat penurunan kecemasan yang dialami oleh responden menjelang operasi. Hal demikian dapat terjadi dikarenakan guided imagery mengajarkan untuk fokus pada imajinasi positif yang dapat menimbulkan keadaan yang rileks (Nguyen, 2012). Saat tubuh dalam keadaan rileks, saraf parasimpatis bekerja menekan saraf simpatetis saat cemas (Bellack \& Harsen, 1997, dalam subandi 2002). Adapun cara kerja guided imagery adalah dengan terfokus pada pengalaman yang menyenangkan serta dengan nafas yang tetap teratur. Hal ini disampaikan oleh Kumar (2009) bahwa pernapasan yang teratur dan fokus terhadap sesuatu membantu mengubah udara menjadi energi yang positif. Seseorang yang mengalami kecemasan seringkali terfokus pada pemikiran negatif, perasaan takut dan khawatir terhadap hal yang akan terjadi di masa mendatang tanpa alasan yang jelas. seseorang mengalami depresi dan kecemasan atau tidak sehat secara psikologis dikarenakan reaksi terhadap pemikirannya sendiri (Fisher \& Wells dalam Pomerantz, 2014).
Pada guided imagery, responden diminta untuk fokus pada pengalaman yang menyenangkan serta melibatkan indera untuk ikut merasakan keindahan tersebut. Dengan membayangkan waktu dan tempat favorit dalam semua keindahan sensori - pemandangan, suara, bau, perasaan - dapat menghasilkan respon emosional yang positif sebagai distraksi yang menyenangkan untuk mengalihkan perhatian dari suatu ketidaknyamanan (Naparstek, 2007). Hal ini sesuai dengan teori multimode yang dinyatakan Jhonston dan Heinz (1978) dalam Reed (2011) bahwa kecenderungan seseorang dan tuntutan tugas menentukan tahap pemrosesan informasi dimana informasi tersebut diseleksi. Model seleksi tersebut mengumpulkan informasi mengenai pesan terbaru, namun mengurangi kapasitas pesan sebelumnya; sehingga pemahaman seseorang terhadap informasi sebelumnya akan menurun sejalan dengan usaha untuk lebih fokus memproses informasi terbaru (Reed, 2011).

Pada intervensi guided imagery, responden diminta untuk seolah-olah dapat melihat, mendengar, mencium, meraba serta merasakan pengalaman menyenangkan yang telah dialaminya. Dalam hal ini terjadi proses interaksi antara pusat-pusat intelektual di otak yang dapat mengakibatkan perubahan psikomotor (Mas'ud, 2001); dalam penelitian ini responden tersenyum setelah diminta untuk membayangkan hal tersebut. Ketika proses membayangkan, pengalaman yang 
menyenangkan tersebut disampaikan oleh pengelihatannya ke pusat pengolahan informasi di bagian kortex sereberi. Sedangkan kortex visual primer dan kortex asosiasi visual diaktifkan untuk membayangkan apa yang tidak dilihatnya namun pernah terlihat oleh responden.

Pada penelitian ini, peneliti menggunakan musik untuk membantu responden segera memasuki kondisi rileks. Musik yang digunakan merupakan musik dengan irama yang pelan dan konsisten. Adanya musik akan semakin meningkatkan efektivitas guided imagery dalam merubah keadaan; yakni menurunkan rasa sakit dan meningkatkan aktifitas fokus (Naparstek, 2007). Selain teknik intervensi yang diberikan, keberhasilan intervensi guided imagery tersebut juga tampaknya ditunjang dengan kesediaan responden untuk mengikuti intervensi atas kemauan dan kesadaran diri sendiri, serta keaktifan atau keterlibatan partisipan secara penuh selama menjalani sesi intervensi termasuk melakukan latihan secara mandiri di rumah. Selama intervensi guided imagery dihentikan, diharapkan responden masih mengingat efek rileks yang ditimbulkan. Hal ini berkaitan dengan memori responden terhadap pengalaman yang menyenangkan tersebut. Sebagaimana yang disampaikan dalam Solso, et al., (2007) bahwa salah satu faktor yang memperkuat memori terhadap sesuatu adalah pengulangan.dalam hal ini pengulangan yang dimaksudkan adalah latihan secara mandiri dengan mengulang melakukan guided imagery secara rutin. Peneliti juga menduga, terdapat variabel lain yang tidak dapat di kontrol oleh peneliti terkait dengan stressor yang muncul dari lingkungan responden.

\section{E. KESIMPULAN DAN SARAN \\ Kesimpulan}

Tingkat kecemasan pasien sebelum dilakukan teknik distraksi guided imagery di RSUD Linggajati Kuningan termasuk dalam kategori sedang.

Tingkat kecemasan pasien sesudah dilakukan teknik distraksi guided imagery di RSUD Linggajati Kuningan termasuk dalam kategori ringan mengalami peningkatan.

Terdapat pengaruh pemberian teknik distraksi guided imagery terhadap tingkat kecemasan pada pasien pra bedah di RSUD Linggajati Kuningan.

\section{Saran}

Hasil penelitian ini diharapkan menjadi masukan yang positif dalam mengembangkan tindakan - tindakan keperawatan yang dapat diberikan dalam pelayanan dan asuhan keperawatan. Selain itu, perlu mengoptimalkan pelayanan dalam membantu pasien dalam menghadapi kecemasan yang dialaminya.

\section{DAFTAR PUSTAKA}

Hawari,D. 2006. Manajemen Stress, Cemas dan Depresi. Jakarta : FKUI. 
Notoatmodjo, S. 2010. Metodologi Penelitian Kesehatan. Jakarta. Rineka cipta.

Potter, P.A, Perry, A.G. Buku Ajar Fundamental Keperawatan : Konsep, Proses, dan Praktik. Edisi 4.Volume 2.Alih Bahasa : Renata Komalasari, dkk.Jakarta: EGC. 2005.

Sheldon, Lisa K, 2009. Komunikasi Keperawatan : Berbicara dengan pasien, Edk2, Alih Bahasa Tinia stella, Editor Amalia Safitri, Erlangga, Jakarta.

Snyder, M \& Linquist, R. ( 2002 ). Complementary alternatife Therapies in nursing. New york: Springer Publishing Company.

Stuart, G.W \& Laraia, M. T. ( 2005 ). Principle and practice of pscychiatric nursing ( $8^{\text {th }}$ edition $)$. St.Louis : Mosby.

Stuart,G. W. 2006. Buku Saku Keperawatan Jiwa. Ed. 5. Alih bahasa : Ramona P. Kapooh. : EGC.

Stuart, G. W.\& Sudeen 2007.Buku saku keperawatan jiwa. Edisi 5. Alih bahasa : Romana P. Kapoh. Jakarta. EGC.

Suliswati, 2005. Konsep Dasar Keperawatan Jiwa, EGC.Jakarta. 